\title{
Teachers' Perception about Effects of Teacher Training Workshop on Professional Skills of Teachers Teaching at Federal Government Educational Institutions
}

\author{
Muhammad Akram Shakir, Muhammad Javed, Anila Sana Akhtar \\ University of Bahawalpur
}

\begin{abstract}
Teachers' professional skills are known as ability of higher-level cognition and knowledge acquired for the purpose of professional growth in career development. Teacher training workshop is a forum which bestows an opportunity of motivation and enhancement of professional skills in different disciplines and areas. The prime purpose of the research was to investigate the effect of teacher training workshop on professional skill of Federal Government Educational Institutions' teachers in Lahore region. It was evaluative in nature and quantitative research approach was adopted to acquire the research objectives. Two hundred (100 male and 100 female) participants of teachers' training workshop were randomly selected as sample for the study. The tool of this research study was a questionnaire formulated by the researchers. Data were collected from those teachers who participated in the workshop conducted in FGEIs Lahore region. The pilot study was also carried out by the researchers in order to validate the research tool. In this connection, the opinions of three experts were sought for the validation of the research tool. The experts in the field of test and measurement verified face validity and content validity. Reliability was also drawn through administering the tool to 30 FG teachers who were not part of the sample study at Lahore. Among them 50\% were male and $50 \%$ female. Internal consistency coefficient using Cronbach Alpha was tested for reliability, the calculated value was0.86. As regards the findings of this research, most of the participants opined that the teacher training workshop promulgates significant effects on the professional enhancement of faculty members. In addition to that, this workshop program should be closely monitored and followed to seek feedback from the teachers who are executing and exercising their practice into the institutions. Therefore, it is recommended that new knowledge and skills should be inculcated during workshop for the sake of teachers' professional development.
\end{abstract}

\section{Introduction}

The requirement of quality education in all essential components of educational programmes, i.e. curriculum, assessment, conducive learning environment and current trends in society means teachers have to continuously acquire training and participate in teacher training workshops. It indicates that teachers enhance and develop knowledge, attitude and all skills that are effective for student learning. Accordingly, Darling-Hammond [12] believes that the most crucial factor in students' academic learning is the credibility of the teachers. Rhoton and Stile [13] suggest that competency of the teacher can possess over 40 percent contribution in students' learning and achievement. Keeping in view the importance and quality of teachers, it is crucial to refresh their subject knowledge and pedagogical skills for implement the changings. Thus, a myriad of teachers in Pakistan look not to feel essential and acknowledge the significance of teacher training programmes. The current empirical research work investigated teachers' perception about effects of teacher training workshop on Professional Skills. Teachers training is elaborated in a host of ways. Villegas - Reimers [1] describes it as enhancement in an individual in his or her professional skills. The University of Delaware [7] defines teachers training expertise as; competency of common teachers to acknowledge and possess the responsibility for developing not only their own expertise but also the prevailing professional practices.

The world has become global village. The era of information and technology keeps on creating new knowledge and information so the knowledge is not being deemed as static and stationary in this period. The changing and expanding world demand updated knowledge and new skills from the individuals to sustain in the global society. In the same time the teachers may not stand effective, if all the individuals have not acquired new knowledge and skills. It was also discussed and mentioned by Holmes [6] that the existing level of knowledge cannot be stagnated 
because this knowledge keeps on developing and changing following each moment of period and one has to keep in touch with it exclusively. All the traditional teaching methods used by teachers have been changed and these will also be modified in future. The old methods may not be in practice in future [11].

The philosophy of teacher training workshops is the part and parcel of different nature of the academia and teacher education. The pivotal intention of teacher training workshop in its streams and specific disciplines is to disseminate and communicate the knowledge, skills, in order to refine the attitudes and habits so that the personality of the teacher may be restructured in a positive way. Extra efforts are also made to reduce and lessen the exercise of the hit and miss procedure; and preserve time, energy, money and difficulties of the students and the academic mentor [7].

It was reported by Guskey [5], that teacher training workshop is a continuous and systematic forum that aims to improve the individuals "cognition level and effective skills so that the learning achievement of the learner may be enhanced. Ball [1] pointed out and distinguished in an imperil research that there is clear and crystal discernment among professional skill, professional training and professional support. Professional skill refers to modification and betterment in all three domains; namely, knowledge, skill and attitude. It also focuses on theory and research-based knowledge. Professional training may exclusively encompass short courses, workshops, conferences and psychomotor skills. Professional supports are aimed to enhance the job understanding, description and performance [4].

In Pakistan, government and nongovernment entities have made efforts and endeavor to impart training the teachers at different levels [9]. Professional training is the radicle and fundamental requirement for the recruitment of teachers at every organization of government or non-government pre requisite where the quality and standard of teacher training is dream in terms of some basic elements such as quality of teachers, educational background, social respect of a teacher, acceptance of mindset of a teacher, highly equipped with knowledge and motivated trainers, resources and selection of audio visual aids are not standardized and according to requirement. The prevailing training is in of the view to manage knowledge gapes and uplift and follow up learned skills. Teachers acquire upgraded and ones of concepts, perceive new expertise, share new ideas, adamant new attitude and believe about teaching learning process. Teacher training is abruptly developed when resourcing, guest speakers and peer discussion are administered. This programme will certainly take essential changes that shall fulfill the requirements of academic reforms that develop existing professional skills for each individual.
Research also indicates that positive development takes place in teachers' expertise when they exchange highly sustained professional skills [11].

A myriad of empirical studies Komba [15] have disseminated a communicated appropriate attitude of teachers towards teacher training workshop. These studies have highlighted that professional skills possess the ability and potential to equip teachers with basic pedagogical skills and keep them abreast with the latest technological strategies.

\section{Master Trainers Program}

The training branch of Directorate of Federal Government Educational Institutions (cantt/garrisons) Rawalpindi aims at teachers' capacity building and professional development so that the teacher could be well equipped and having updated knowledge and skills to provide the quality of education to the wards of armed personnel as well as civilians. That is what one-week master trainers workshop was managed for FGEIs teachers to enhance their professional skills [8]. A myriad of batches of teacher training workshops have been organized so far by FGEI offices in which different teachers of concerned region were imparted professional skills in the areas of teaching and management. They are performing their duties in their concerned institutions in a better way [5].

\section{Rationale of the study}

FGEIs (c/g) Directorate has taken the challenging task of imparting professional training to FGEIs teachers and it has successfully administered hundreds of professional development courses up to March, 2016. Hence, the effect of these centrally organized teacher training workshops has not been empirically evaluated. FGEIs Directorate intends to improve the quality of training workshops [11]. The researchers chose the subject study to analyze the effectiveness of the training program. This empirical research is not the finalization but the beginning point of forth coming of the workshops in future.

\section{Context of the study}

Teachers' significant role in the socio-economic development of the country and nation is highly appreciated and acknowledged at all levels. The developed countries like Japan and China which possess the same status and life following embossed on global map and are considered leading countries of the world. The secret of their leading role and developing is in their sustained and strong education system. Developed education system lies upon predetermined and clear crystal objectives, policies, sustained economy and motivated teachers. 
Mentioned above countries prioritized and encompassed teacher training at all grades. Pakistan is lagging behind in the area of teacher education and professional competency due to some reasons. For provincial schools, teacher training programs are organized by Directorate of Staff Development. There was no faculty training programs for FGEIs in Pakistan at any level accept pre-service training. Inspector General of Training \& Evaluation (IGT \& E) foremost deemed prerequisite and necessary and began imparting training to the teachers. After going through the myriad of difficulties, FGEI part of IGT managed and administered teacher training workshops throughout Pakistan with speedy momentum. In the current empirical study, the researchers identified the effectiveness of teacher training workshop on professional skill of FGEI teachers in Lahore region. The skills under discussion are the degree of knowledge acquired during the workshop, classroom management skills, educational assessment skills, pedagogical skills and professional skills.

Human resource department (HRD) is responsible for the management of human capital/ human development required in the educational institutions efficiently and effectively [3]. Keeping in view the significance and pivotal role of human resources in $\mathrm{FGEI}(\mathrm{C} / \mathrm{G})$, the teacher training workshop mechanism was devised and suggested by the fore mentioned organization. Finally, it was named as Academic Monitoring \& Evaluation Cell/Branch. Professional development of the faculty members is conceived in the spirit of Excellency of Teaching. The main intention of the branch is to provide and fulfill the prerequisite requirement of quality of education and to make better professional skills. An effective mechanism of training is fundamentally based for increase of teachers' professional skills. Refined and up to date teaching techniques are helpful for creating conducive learning environment in the classroom. Entirely total growth of a teacher involves all the fundamental and radical teaching strategies (i.e. Lesson planning, classroom management, Audio Visual aids and use of IT, social skills, assessment, activity-based teaching, homework, feedback and follow up). Bubb [3] stated in his study that this is an era of information technology and communication which has brought revolution in all spheres of life. It also demands teachers to have skills of information technologies, new teaching techniques and strategies for the betterment of pedagogical abilities and content dissemination to the teacher and taught [10].

It is globally acknowledged and appreciated matter of consideration that the mile stone and target of accredited / extensive education cannot be bagged except modernizing and increasing pedagogical abilities, content competencies, deriving moves and answerability of the faculties [2]. As per formulation and conceived by the Inspector General of Training \&
Evaluation (IGT \& E), an exclusive cell and section was named as professional development and Academic Monitoring \& Evaluation Branch. That was inaugurated and managed in the premises of FGEIs Directorate Rawalpindi. The main and prime purpose of this cell was to exclusively monitor the matters of academic growth as well as teacher training workshop mechanism. So that it may create a vibrant and committed faculty to look after and assess the educational effectiveness of its academic institutions in Pakistan. Such evaluative branches have also been set up in all the regional offices throughout Pakistan.

The teaching and non- teaching faculty members including administrative stakeholders of FGEIs $(\mathrm{C} / \mathrm{G})$ require a vast and extensive exposure concerning to all the academic and professional skills needed for successful institutions. A successful and effective teacher must have extensive knowledge regarding pedagogical skills, and professional skills. The pivotal and hub of education is such teacher training workshop which intends to improve effectiveness of professional developmental mechanism in Pakistan. In view of the situation, the researchers took keen interest to investigate Teachers' perception of the effectiveness of the training programme organized at FGEI (C/G).

\section{Objectives of the Study}

The study aims to investigate

1.Teachers' perception of the effectiveness of teacher training workshop on professional skills of FGEI teachers.

2. Teachers' perception of Professional skills of FGEI teachers.

The main aim of the proposed workshop was to disseminate a comprehensive literature review of empirical study on relationship between teachers' training workshops and professional skills. The researchers attempted to answer the following research questions:

1. What are the perceived effects of teacher training workshop on professional skills of FGEI teachers in Lahore region?

2. What are the perceived professional skills of FGEI teachers in Lahore region?

\section{Methodology}

The prime purpose of this research work is to investigate the teachers' perception of effectiveness of teacher training workshop on professional skills of FGEI teachers. Survey method was developed and designed for conducting this study. The population of this research work was all the Federal Government Educational Institutions of Lahore region. The 
strength of the staff is 750 (seven hundred and fifty). There are 24 (twenty-four) educational male and female institutions of $\mathrm{FGEI}(\mathrm{C} / \mathrm{G})$ at Lahore region.

Purposive sampling technique was adopted to seek the sample from the entire population. There were two hundred (100 male and 100 female) participants of the workshop as sample. The self-constructed instrument in the form of questionnaire was utilized to administer the survey. The participants were requested to choose the options as required and applicable to them. There was only one independent variable (teachers' training workshops) which was conducted as an in-service training programme by the educational organization. The dependent variable of the training workshop was professional skills of FGEI (C/G) teachers.

The pilot study was also carried out by the researchers in order to validate the research tool. In this connection, the opinions of three experts were sought for the validation of the research tool. The experts in the field of test and measurement verified face validity and content validity. Reliability was also drawn through administering the tool to $30 \mathrm{FG}$ teachers who were not part of the sample study at Lahore. Among them 50\% were male and 50\% female. Internal consistency coefficient using
Cronbach Alpha was tested for reliability, the calculated value was0.86. Data reflected from the tool were used to answer the research question by using descriptive as well as inferential statistics

\section{Results}

\section{Formula for effect size was as under:}

$$
\begin{aligned}
& \text { Eta Squaredt } \underline{\mathrm{t}^{2}}=\mathrm{T}^{2+\left(\mathrm{N}_{2}+\mathrm{N}_{2}-2\right)} \\
& >\mathrm{N}_{1}=\text { Numbers of malesN } \mathrm{N}_{2} \\
& =\text { Numbers of females } \\
& >\text { Values for Standard Eta Square 0.01 } \\
& =\text { Small effect } \\
& >0.06=\text { Moderate effect } 0.14 \\
& =\text { Large effect }
\end{aligned}
$$

Research Question 1: What are the perceived effects of teacher training workshop on professional skills of FGEI teachers in Lahore region?

$\mathrm{H}_{\mathrm{o}}$ There is no statistically significant effect of teacher training workshop on professional skills of FGEI teachers at Lahore Region.

Table 1. Effect of teacher training workshop on professional skills of FGEI Teachers at Lahore Region

\begin{tabular}{lccccc}
\hline Variable & Gender & N & M & SD & Sig \\
\hline Teacher training workshop and & Male & 99 & 27.61 & 4.62 & 0.017 \\
professional skills of FGEI teachers. & Female & 101 & 25.90 & 5.44 & \\
\hline
\end{tabular}

Table 2. Statistical features with Effect Size

\begin{tabular}{lllcccc}
\hline Objective & $\begin{array}{l}\text { Independent } \\
\text { variable }\end{array}$ & $\begin{array}{l}\text { Dependent } \\
\text { variable }\end{array}$ & $\begin{array}{c}\text { Agreed } \\
\%\end{array}$ & $\begin{array}{c}\text { Disagreed } \\
\%\end{array}$ & $\begin{array}{l}\text { P-V } \\
\text { Effect } \\
\text { size }\end{array}$ \\
\hline $\begin{array}{l}\text { Effect of teacher training workshop } \\
\text { on professional skills }\end{array}$ & $\begin{array}{l}\text { Teacher } \\
\text { Training }\end{array}$ & $\begin{array}{l}\text { Professional } \\
\text { skills }\end{array}$ & $82.5 \%$ & $11.5 \%$ & 0.017 & 0.02 \\
& $\begin{array}{l}\text { Workshop } \\
\text { (TTW) }\end{array}$ & & & & & \\
& & & & & \\
\hline
\end{tabular}

Significant level is $\leq 0.05$

The Table 2 reveals that 0.02 Effect size as per Eta Squared formula indicates that there is small effect of teacher training workshop on professional skills of the teachers.
Question 2: What are the perceived professional skills of FGEI teachers in Lahore region?

The following responses were acquired from two hundred participant teachers from 24 FGEIs(c/g) in Lahore Region and result tabulated as follows. 
Table 3. Frequencies and percentages of the responses in (TPSMS) about perception of professional skills

1-You think the training has had a good effect on the performance of your colleagues, students and schools. (ProfessionalSkills) 2-You think the training achieved the intended objectives.

3-I have a better understanding of different learning styles.

4-The purpose of holding the workshop was to up-grade participants' knowledge, skills, etc in Multigame teaching so that they can work more efficiently.

5-The teacher training workshop was useful for your professional development.

6-We were encouraged to discuss and to find solutions to our real-life problems.

7-I was encouraged and motivated to think critically about my experiences in light of new knowledge.

8-Trained teacher has Potential for professional growth (possibility of improving one's own professional skills) Pedagogical Skills

9-A variety of teaching and learning approaches were used in the course.

10-I will be able to improve my pedagogical ability by training.

11-I feel more knowledgeable about constructivism and communicative language teaching.

12-I have a better understanding of different pedagogical styles.

13-Individual differences among students play an important role for the teacher to adopt a teaching method.

14-Use of motivation skills facilitates the teacher's job.

15-My English class includes more peer to peer interaction, group and pair work now.

16-I think, classroom management can promote the professional skills. (Classroom Management Skills)

$\begin{array}{llllll}\text { Frequency } & 14 & 9 & 12 & 98 & 67 \\ \text { Percentage } & 7.0 \% & 4.5 \% & 6.0 \% & 49.0 \% & 33.5 \% \\ & & & & & \\ \text { Frequency } & 12 & 42 & 18 & 112 & 16 \\ \text { Percentage } & 6.0 \% & 21.0 \% & 9.0 \% & 56 . \% & 8.0 \% \\ \text { Frequency } & 6 & 7 & 27 & 124 & 36 \\ \text { Percentage } & 3.0 \% & 3.5 \% & 13.5 \% & 62 . \% & 18 . \% \\ & & & & & \\ \text { Frequency } & 8 & 16 & 22 & 90 & 64 \\ \text { Percentage } & 4.0 \% & 8.0 \% & 11.0 \% & 45.0 \% & 32.0 \% \\ & & & & & \\ \text { Frequency } & 9 & 23 & 27 & 95 & 46 \\ \text { Percentage } & 4.5 \% & 11.5 \% & 13.5 \% & 47.5 \% & 23.0 \% \\ \text { Frequency } & 6 & 13 & 37 & 98 & 46 \\ \text { Percentage } & 3.0 \% & 6.5 \% & 18.5 \% & 49.0 \% & 23.0 \% \\ & & & & & \\ \text { Frequency } & 1 & 14 & 24 & 103 & 58 \\ \text { Percentage } & 0.5 \% & 7.0 \% & 12.0 \% & 51.5 \% & 29.0 \%\end{array}$

$\begin{array}{llllll}\text { Frequency } & 2 & 11 & 25 & 100 & 62\end{array}$

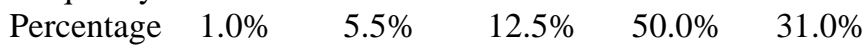

$\begin{array}{llllll}\text { Frequency } & 11 & 27 & 26 & 96 & 40\end{array}$

$\begin{array}{llllll}\text { Percentage } & 5.5 \% & 13.5 \% & 13.0 \% & 48.0 \% & 20.0 \%\end{array}$

$\begin{array}{llllll}\text { Frequency } & 4 & 10 & 36 & 108 & 42\end{array}$

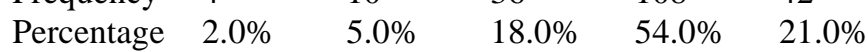

$\begin{array}{llllll}\text { Frequency } & 4 & 21 & 31 & 106 & 38\end{array}$

$\begin{array}{llllll}\text { Percentage } & 2.0 \% & 10.5 \% & 15.5 \% & 53.0 \% & 19.0 \%\end{array}$

$\begin{array}{llllll}\text { Frequency } & 2 & 12 & 28 & 113 & 45\end{array}$

$\begin{array}{llllll}\text { Percentage } & 1.0 \% & 6.0 \% & 24.0 \% & 56.5 \% & 23.5 \%\end{array}$

$\begin{array}{llllll}\text { Frequency } & 7 & 7 & 10 & 99 & 77\end{array}$

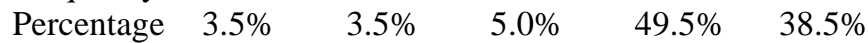

$\begin{array}{llllll}\text { Frequency } & 1 & 14 & 09 & 101 & 75\end{array}$

$\begin{array}{llllll}\text { Percentage } & 0.5 \% & 7.0 \% & 4.5 \% & 50.5 \% & 37.5 \%\end{array}$

$\begin{array}{llllll}\text { Frequency } & 3 & 15 & 38 & 118 & 26\end{array}$

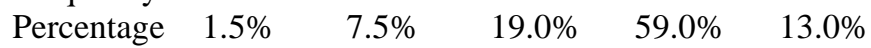

$\begin{array}{llllll}\text { Frequency } & 5 & 6 & 15 & 82 & 92\end{array}$

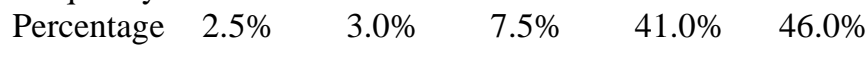


17-I have an increased awareness of the characteristics and needs of classroom management.

18-Classroom Management is something different from the teaching in class.

19-I am equipped with variety of instructional strategies to promote student engagement.

20-Teacher training Workshop helps a teacher to feel a little uneasy among students of multi-culture.

21-Management skills are necessary for the teachers to utilize them in the teaching learning situations.

22-I feel better informed and knowledgeable about the new classroom management techniques

23-I know better how to evaluate and use assessment techniques according to my classroom needs.

24-I have the ability to select best and latest assessment strategy for monitoring students learning.

25-I have the ability to construct appropriate assessment strategy for monitoring students learning.

26-I have the ability to use appropriate assessment strategy for monitoring student learning.

27-I feel confident when students are involved in discussion after my motivational presentations.

28-I am a fast learner when picking up better teaching techniques in comparison to other teachers.

29-Teacher training workshop motivates the Potential for advancement (e.g., possibility of assuming different positions in the profession). Motivation gii98yuiiy

30-I have a better self-concept, satisfaction, and confidence in my ability as a teacher now.

\begin{tabular}{|c|c|c|c|c|c|}
\hline Frequency & 1 & 9 & 24 & 119 & 47 \\
\hline Percentage & $0.5 \%$ & $4.5 \%$ & $12.0 \%$ & $59.5 \%$ & $23.5 \%$ \\
\hline Frequency & 11 & 24 & 34 & 89 & \\
\hline Percentage & $5.5 \%$ & $12.0 \%$ & $17.0 \%$ & $44.5 \%$ & $21.0 \%$ \\
\hline Frequency & 5 & 17 & 28 & 125 & 25 \\
\hline Percentage & $2.5 \%$ & $8.5 \%$ & $14.0 \%$ & $62.5 \%$ & $12.5 \%$ \\
\hline Frequency & 8 & 43 & 21 & 98 & 30 \\
\hline Percentage & $4.0 \%$ & $21.5 \%$ & $10.5 \%$ & $49.0 \%$ & $15.0 \%$ \\
\hline Frequency & 0 & 11 & 12 & 97 & 80 \\
\hline Percentage & $0.0 \%$ & $5.5 \%$ & $6.0 \%$ & $48.5 \%$ & $40.0 \%$ \\
\hline Frequency & 2 & 18 & 20 & 117 & 42 \\
\hline Percentage & $1.0 \%$ & $9.0 \%$ & $10.0 \%$ & $58.5 \%$ & $21.0 \%$ \\
\hline Frequency & 2 & 6 & 22 & 120 & 50 \\
\hline Percentage & $1.0 \%$ & $3.0 \%$ & $11.0 \%$ & $60.0 \%$ & $25.0 \%$ \\
\hline Frequency & 1 & 12 & 24 & 126 & 37 \\
\hline Percentage & $0.5 \%$ & $6.0 \%$ & $12.0 \%$ & $63.0 \%$ & $18.5 \%$ \\
\hline Frequency & 2 & 9 & 29 & 129 & 31 \\
\hline Percentage & $1.0 \%$ & $4.5 \%$ & $14.5 \%$ & $64.5 \%$ & $15.5 \%$ \\
\hline Frequency & 1 & 21 & 19 & 112 & 47 \\
\hline Percentage & $0.5 \%$ & $10.5 \%$ & $9.5 \%$ & $56.0 \%$ & $23.5 \%$ \\
\hline Frequency & 0 & 13 & 15 & 108 & 64 \\
\hline Percentage & $0.0 \%$ & $6.5 \%$ & $7.5 \%$ & $54.0 \%$ & $22.0 \%$ \\
\hline Frequency & 0 & 18 & 33 & 106 & 43 \\
\hline Percentage & $0.0 \%$ & $9.0 \%$ & $16.5 \%$ & $53.0 \%$ & $21.5 \%$ \\
\hline Frequency & 5 & 17 & 31 & 87 & 60 \\
\hline Percentage & $2.5 \%$ & $13.5 \%$ & $15.5 \%$ & $43.5 \%$ & $30.5 \%$ \\
\hline Frequency & 2 & 3 & 31 & 101 & 63 \\
\hline Percentage & $1.0 \%$ & $1.5 \%$ & $16.5 \%$ & $50.5 \%$ & $31.5 \%$ \\
\hline
\end{tabular}

$1^{\text {st }}$ Group (St.D=Strongly Disagree, D=Disagree,) Un.D=Undecided, $2^{\text {nd }}$ group $($ St. A =Strongly Agree, $\mathrm{A}=$ Agree,) Two groups were formulated i.e. agreed and disagreed for interpretation of the data.

The table reveals that $82.5 \%$ participants agreed that teachers' training workshops affected positively professional skills whereas $11.5 \%$ disagreed. On the other hand $75 \%$ participants agreed that teachers' training workshops improved the participants' pedagogical skills however $7 \%$ of them disagreed. The participant teachers who agreed that teachers' training workshops increased their classroom management were $86 \%$ whereas $5.5 \%$ disagreed with it. Those who gave their opinion in the support that teachers' training workshops enhanced their assessment skills were $85 \%$ whereas $4 \%$ disagreed.

\section{Discussion}

The primary aim of the present study was to explore the effectiveness of teacher training workshop on professional skills as assessed by the participants' perception by the teachers themselves. The effect size of this study is small on professional skills and is closely related to the teacher training workshop's objectives. It is concluded that participants felt 
satisfaction at the workshop. There was an introduction of new strategies such as audio-visual aid and assessment techniques. This empirical research extends previous research on the effectiveness of efficacy of teacher training workshop's packages to improve just only pedagogical skills. Shore (1995) stated in his study that mostly studies just assess the level of effects on knowledge acquired by the participant and not measure contribution of learned information in true conducive teaching learning environment. Quilitch [14] concluded in his empirical study that the workshop did not affect too much enhanced employees with boarding institutional environments. The present results addressed comprehensive approach that includes professional, pedagogical, assessment and classroom management skills. The present workshop motivated the teachers to encourage other teachers for participating in such workshops in future. In this study, almost all the teachers extended their views that they improved their lesson planning skills and acquired to utilization of audio visuals aids in a better way after participating the workshop. The study conducted at FGEI, found that teacher training workshop on professional skills are effective for teachers. Variables mentioned in the present study such as classroom management, pedagogical, assessment and professional skills are the factors and indicators of teacher performance, which lead to the quality education.

On the basis of data analysis, it was found that the teachers focused on specific objective of the presentation and took the significant points during the workshop. Most of the teachers improved their professional skills and were able to prepare adequate assessment tools according to the students' requirements. It was also recognized and acknowledged that a significant betterment in the area of professional skills was found. However, Male teachers exceeded from female teachers and acquired more ability /competency in the educational sector of assessment skills. On the other hand, females learnt classroom management and pedagogical skills which is an amazing and interesting fact that was highlighted. Male teachers paid more heed toward seeking higher professional skills than female teachers. A restriction of this study was that some of the teachers' feedback in real classroom environment was not performed, although training polished their expertise in respective category. In a study carried out in the country of Nepal, mostly $96 \%$ of the participant agreed that there was a restriction of assessment in the workshop. $61 \%$ teachers reported that their personal objectives were fulfilled, and objectives of that training workshop were clear and crystal. In another training workshop, $81 \%$ teachers reported that they were able to give lecture efficiently and effectively following the workshop.

\section{Conclusion}

The training workshop was informative and that the teachers who participated acquired teaching techniques and assessment practices. All the participants demonstrated and extended higher emotions of interest for organizing more teacher training workshops in future. It was also concluded that teachers should pay their attention to continuous effort on enhancing the professional skills to such an extent so that student may be satisfied from the skill and knowledge of the teacher and accommodate their students learning more efficiently. The current workshop has enhanced their ability and skill of teaching which may be effective in real situation of classroom management. The feedback of male and female participants also supported the FGEI's employees to improve their professional skills and also motivated them to attend such workshops in future. Similar teacher training workshops should be organized on periodic basis to support teachers to comprehend, manage and prioritize their career opportunities as FGEI teachers. Newly acquired skills and practices may be replicated by the highly learned communities where the knowledge and experience of teachers are acknowledged and appreciated and that opportunity are bestowed to exchange their professional skills.

This research suggested that teachers' training workshops should deliberately be observed and exclusively reviewed by the administration and management of FGEI(C/G). Such training workshops and plans should be organized in other regions of Pakistan. The administration should focus on classroom management skill of the teachers. Assessment skills should also need systematical improvement in FGEI set up.

\section{References}

[1] Ball, D. L. (2003). Mathematical proficiency for all students towards a strategic research and development program in mathematics education. Teaching Skillful Educational Leadership, 68(4) 40-45.

[2] Franceis, C. (2001). Mentoring and beginning teachers' workplace learning. Asia pacific journal of teacher eduction.

[3] Gibbs, G. \& Coffey, M. (2004). The impact of training of university teachers on their teaching skills, their approach to teaching and the approach to learning of their students, Active Learning in Higher Education, 5,85- 87.

[4] Gronlund, N. E. (2006). Assessment of student achievement (8th ed.). Boston: Pearson.

[5] Guskey, T. (2000). Evaluating professional development. Evaluating professional development. 
[6] Holmes, E. (2005). Teacher Well-being: Looking after yourself and your career in the classroom. New York: RoutledgeFalmer.

[7] Hussain,S. (2004). Effectiveness of teacher training in developing professional attitude of prospective secondary school teachers (Unpublished Doctoral dissertation's thesis). University of Arid Agriculture, Rawalpindi.

[8] Iqbal, D. M. (2019, March 4). Training, Monitoring and Evaluation Branch. Retrieved from FG Educational Institutions (C/G) Directorate Rawalpindi: http://www.fgeicg.gov.pk/Trg-M\&E/details.php?pid=2

[9] Punjab, G. o. (2007b). National curriculum for early chilhood education. Lahore: Directorate of staff development and UNESSCO.

[10] Schmitz, S. A. (2003). The development and testing of a compendium of model strategies for performance improvement of special education personnel of $\mathrm{K}-12$ schools. (Unpublished Doctoral Thesis) Iowa State University. Retrieved March 5, 2019, from https://lib.dr.iastate.edu/cgi/viewcontent.cgi?article $=2412$ \&context=rtd

[11] Zulfiqar, M. S. (2016). Teachers' perceptions about inservice training at Federal Government educational Institutions (Cantts/ Garrisons). Lahore:(Unpublished doctoral dissertation's thesis). Lahore: University of Education, Lahore.

[12] Darling-Hammond, L., (2000). Teacher Quality and Student Achievement: A Review of State Policy Evidence. Education Policy Analysis Archives, Vol. 8, No. 1, ISSN 1068-2341.

[13] Rhoton, J., \& Stiles, K. (2002). Exploring the professional development design process: Bringing an abstract framework into practice. Science Educator. 11(1), $1-8$.

[14] Quilitch, H.R. (1975), A Comparison Of Three StaffManagement Procedures. Journal of Applied Behavior Analysis, 8: 59-66. doi:10.1901/jaba.1975.8-59.

[15] Komba, S., (2008). The impact of communication skills course on students' development of communicative abilities. Unpublished M.A. Education Dissertation. University of Dar es Salaam, Tanzania. 